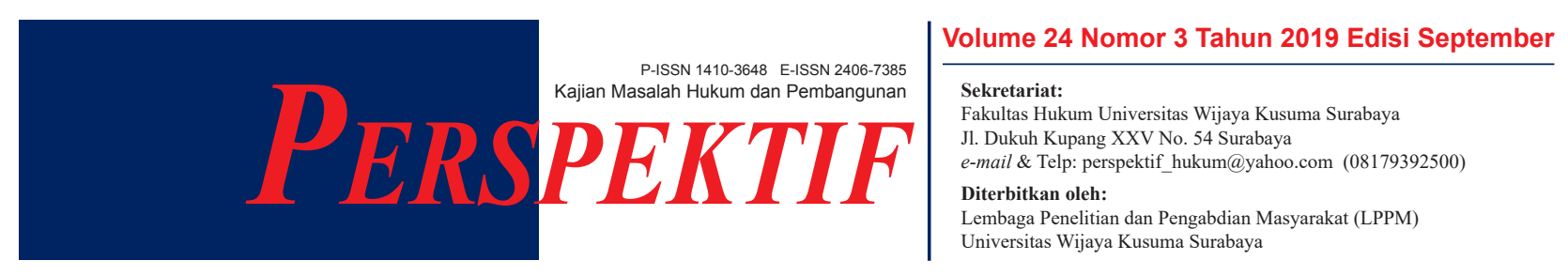

\title{
EKSISTENSI PT. SUCOFINDO (PERSERO) DALAM MENJAMIN KEHALALAN PRODUK MAKANAN DI INDONESIA MELALUI SERTIFIKASI HALAL
}

\author{
Desy Nurkristia Tejawati \\ Fakultas Hukum, Universitas Wijaya Kusuma Surabaya \\ e-mail: echyn87@gmail.com
}

\begin{abstract}
ABSTRAK
Indonesia merupakan negara yang penduduknya mayoritas beragama Islam sehingga jaminan terhadap kehalalan produk adalah hal yang amat penting sedangkan dikarenakan pengetahuan dan teknologi semakin tinggi maka menimbulkan berbagai macam cara yang digunakan dalam membuat sebuah produk, terutama produk makanan. Pemberian label memberi informasi untuk konsumen atas suatu produk sehingga memberikan keyakinan bahwa produk tersebut telah sesuai dengan harapan mereka. Sebagaimana label halal yang mempermudah konsumen yang beragama Islam dalam memilih makanan yang baik bagi dirinya dan sesuai dengan aturan agamanya dan memenuhi standar dalam keamanan dan kebersihannya. Sertifikasi memiliki makna suatu sertifikat yang berasal dari pihak ketiga yang independen seperti dari PT. SUCOFINDO (Persero). Peran PT. SUCOFINDO antara lain memberikan ketetapan mengenai standar, norma, dan kriteria jaminan produk halal, serta melakukan penerbitan dan mencabut sertifikat dan label halal dari suatu produk, registrasi, sertifikasi halal pada produk luar negeri, serta melakukan sosialisasi, edukasi, dan publikasi pada produk halal. PT. SUCOFINDO memiliki laboratorium dengan peralatan dan teknologi terkini guna mendukung proses uji halal, diantaranya PCR (Polumerase Chain Reaction) sehingga dapat melakukan deteksi terhadap DNA babi serta Chromatography (GC dan HPLC) guna mendeteksi zat alkohol atau ethanol.
\end{abstract}

Kata Kunci: Sertifikasi Halal; Jaminan Produk Halal, Pihak Ketiga

\begin{abstract}
Indonesia is a Muslim majority country, so guaranteeing the halal status of the product is very important. The development of technology gave birth to a variety of ways that can be used in making a product, be it food, drink, or cosmetics. Labeling is carried out on a product with the aim of providing information on the consumer of the product, whether in accordance with what he expected. Likewise, the halal label will make it easier for Muslim consumers to choose products that comply with their religious rules, and meet safety and hygiene standards. Halal label must be with halal certification, which comes from an independent third party, one of which is PT. SUCOFINDO (Persero). The role of PT. SUCOFINDO, among others, provides provisions regarding standards, norms. and halal product guarantee criteria, issuance and revocation of halal products, registration, certification of halal products from abroad, as well as disseminating, educating and publishing on halal products. PT. SUCOFINDO has laobratorium with the latest equipment and technology to support the halal test process, including PCR (Polumerase Chain Reaction) so that it can detect pig DNA, and Chromatography (GC and HPLC) to detect alcohol or ethanol.
\end{abstract}

Keywords: Halal Certification; Halal Products Insurance; Third Party 


\section{PENDAHULUAN}

Globalisasi, perdagangan dan Masyarakat Ekonomi Asia (MEA) memiliki dampak terhadap meningkatnya peredaran produk makanan dan minuman baik yang berasal dari dalam maupun luar negeri. Produk makanan dan minuman tersebut diharapkan memiliki rasa aman, nyaman, tentram dan dapat dikonsumsi oleh konsumen muslim, sebab hal tersebut memberikan kewajiban pada umat Islam untuk melakukan konsumsi makanan dan minuman yang sesuai dengan syariat Islam. ${ }^{1}$

Negara memiliki kewajiban untuk memberikan perlindungan dan menjamin kehalalan produk yang dikonsumsi serta digunakan konsumen yang beragama Islam. Jaminan terkait dengan penyelenggaraan produk halal memberikan kenyamanan, keamanan, keselamatan, dan kepastian ketersediaan produk halal untuk masyarakat dalam menggunakan dan mengkonsumsi produk halal, serta melakukan peningkatan nilai tambah bagi pelaku usaha untuk melakukan produksi dan menjual produk halal. ${ }^{2}$

Industri pangan seharusnya menjadi hal paling sering dijumpai setiap hari dalam lingkungan masyarakat, haruslah adanya ketersediaan secara bermutu dan bergizi di lingkungan masyarakat.Maka dari itu dalam mengkomsumsinya di lingkungan masyarakat harus adanya jaminan dalam produk halal, dimana di negara Indonesia merupakan salah satu negara mayoritas masyarakat penduduknya Muslim terbesar yang memiliki dalam kepercayaannya mengedepankan Halal. ${ }^{3}$

Agama Islam melarang mengkonsumsi makanan atau minuman yang haram karena Allah sudah menjelaskan "Sesungguhnya Allah mengharamkan bagimu bangkai, darah, daging babi dan binatang yang (ketika disembelih) disebut (nama) selain Allah. Tetapi barang siapa dalam keadaan terpaksa (memakainya) sedang ia tidak menginginkannya dan tidak (pula) melampaui batas, maka tidak ada dosa baginya.” pada QS. Al-Baqarah: 173. Dan Allah menyampaikan pada khalifah yang ada di bumi "hai sekalian manusia, makanlah yang halal lagi

\footnotetext{
${ }^{1}$ R. Hendra Halwani. (2003). Ekonomi Internasional dan Globalisasi Ekonomi. Jakarta: Ghalia Indonesia, h. 12.

${ }^{2}$ Abdurrahman Konoras. (2007). Jaminan Produk Halal di Indonesia, Perspektif Hukum Perlindungan Konsumen. Jakarta: Rajawali Press, h. 30.

${ }^{3}$ ibid.
}

baik dari apa yang terdapat di bumi, dan janganlah kamu mengikuti langkah-langkah syaitan; karena sesungguhnya syaitan itu adalah musuh yang nyata bagimu" pada QS. Al-Baqarah: 168.

Indonesia dalam rangka mewujudkan Negara Kesejahteraan atau Welfare State sebagai wujud negara hukum memiliki berbagai upaya, salah satunya yaitu dengan memperhatikan kepentingan masyarakat. Indonesia merupakan salah satu negara di kawasan Asia Tenggara dengan penduduk muslim terbesar di dunia, dalam melaksanakan kehidupan bernegara, Negara Republik Indonesia mempunyai karakteristik yang berbeda dengan negara lain. Kehidupan bernegara di Indonesia banyak dipengaruhi oleh dogma Islam yang diaktualisasikan dalam kehidupan masyarakat, tanpa mengesampingkan kepentingan masyarakat non-muslim. ${ }^{4}$

Seiring dengan kemajuan ilmu pengetahuan dan teknologi di bidang pangan, obat-obatan, dan kosmetik yang berkembang pesat, maka jaminan produk halal merupakan hal yang sangat penting. Hal tersebut memiliki pengaruh dengan adanya pergeseran tata cara pengolahan dan pemanfaatan bahan baku pada pembuatan makanan, minuman, kosmetik, obat-obatan dan produk lainnya yang sederhana dan alamiah menjadi lebih modern, yang memberi peluang untuk adanya pencampuran bahan baku yang halal dan haram baik disengaja maupun tidak disengaja, sehingga butuh pengetahuan multidisiplin. ${ }^{5}$

Jaminan produk halal dilakukan sesuai dengan asas perlindungan, keadilan, kepastian hukum, akuntanbilitas dan transparansi, efektifitas dan efisiensi, serta profesionalitas. Jaminan penyelenggaraan produk halal bertujuan memberikan kenyamanan, keamanan, keselamatan, dan kepastian ketersediaan produk halal bagi masyarakat dalam mengkonsumsi dan menggunakan produk halal, serta

\footnotetext{
${ }^{4}$ Syafrida. "Sertifikat Halal Pada Produk Makanan dan Minuman Memberi Perlindungan dan Kepastian Hukum HakHak Konsumen Muslim". Jurnal Adil. Vol. 7 No. 2 Desember 2016, h. 161.

${ }^{5}$ May Lim Charity. "Jaminan Produk Halal di Indonesia". Jurnal Legislasi Indonesia. Vol. 14 No. 01 Maret 2017, h. 99108.
} 
meningkatkan nilai tambah bagi pelaku usaha untuk memproduksi dan menjual produk halal. ${ }^{6}$

Salah satu pihak yang berwenang dalam melakukan kajian tentang kehalalan suatu produk adalah PT. Superintending Company of Indonesia (Persero) (yang diselanjutnya disebut SUCOFINDO) yang memiliki bidang jasa ISPP yang lebih dikenal dengan perusahaan jasa surveyor. ${ }^{7}$ SUCOFINDO merupakan perusahaan patungan yang dibangun antara Pemerintah Republik Indonesia dengan SGS, Perusahaan inspeksi terbesar di dunia yang berpusat di Jenewa, Swiss. ${ }^{8}$

SUCOFINDO memulai bisnisnya dari perdagangan komoditas pertanian, serta yang terkait dengan kelancaran arus barang dan pengamanan devisa negara dalam ekspor impor. SUCOFINDO, seiring perkembangan dunia usaha, menawarkan inovasi jasa baru yang memiliki basis kompetisinya, antara lain warehousing dan forwading, analytical laboratories, industrial and marine engineering dan fumigation and industrial hygiene, sertifikasi, audit, assessment, konsultansi, pelatihan, dan berbagai kegiatan penunjang terkait, diantaranya pada sektor Pertanian, Kehutanan, Pertambangan, baik Migas maupun Non Migas, Konstruksi, Industri Pengolahan, Kelautan, Perikanan, Pemerintahan Transportasi, Sistem Informatika dan Energi Terbarukan. ${ }^{9}$

\section{PERUMUSAN MASALAH}

Berdasarkan permasalahan, maka penulis merumuskan masalah sebagai berikut: bagaimana kebijakan pemerintah mengenai aspek kehalalan di Indonesia serta eksistensi SUCOFINDO dalam menjamin kehalalan suatu produk bagi konsumen.

\section{METODE PENELITIAN}

Penelitian ini merupakan penelitian hukum normatif, mengingat pembahasan yang dilakukan didasarkan pada pendekatan perundang-undangan.

\footnotetext{
${ }^{6}$ Syafrida. op.it.

${ }^{7}$ SUCOFINDO. https://www.SUCOFINDO.co.id/. Diakses pada tanggal 30 Oktober 2019.

${ }^{8}$ SUCOFINDO. "sejarah singkat SUCOFINDO", https:// www.SUCOFINDO.co.id/id/sejarah-singkat-SUCOFINDO\#. Diakses tanggal 7 Mei 2019.

${ }^{9}$ op.cit.
}

\section{PEMBAHASAN \\ Kebijakan Pemerintah Mengenai Aspek Kehalalan di Indonesia}

Definisi mengenai kata halal adalah akar kata yang memiliki arti "lepas" atau "tidak terikat". Sesutau yang halal artinya sesuatu yang terlepas dari ikatan bahaya duniawi dan ukhrawi. Dalam bahasa hukum, kata halal berarti boleh. Kata ini mencakup segala sesuatu yang dibolehkan agama, baik itu dibolehkan bersifat sunnah, anjuran untuk dilakukan atau makruh, anjuran untuk ditinggalkan, maupun mubah, netral/boleh-boleh saja. ${ }^{10}$

Produk adalah barang dan/atau jasa yang terkait dengan makanan, minuman, obat, kosmetik, produk kimiawi, produk biologi, produk rekayasa genetik, serta barang gunaan yang dipakai, digunakan atau dimanfaatkan oleh masyarakat. Produk halal merupakan produk yang telah dinyatakan halal sesuai dengan syariat Islam. Sedangkan definisi mengenai sertifikasi halal adalah pengakuan kehalalan suatu produk, yang dikeluarkan oleh Badan Penyelenggara Jaminan Produk Halal berdasarkan fatwa halal tertulis yang dikeluarkan oleh Majelis Ulama Indonesia. ${ }^{11}$

Kebijakan Pemerintah Mengenai Aspek Kehalalan di Indonesia berkaitan dengan meningkatnya permintaan produk-produk halal di setiap negara termasuk Indonesia, maka itu pemerintah haruslah memberikan rasa aman dan menjamin kelayakan suatu produk bagi masyarakatnya untuk dikonsumsikan demi menjaga kesehatan dan ajaran agama dalam halal setiap produk. Kita sebagai warga negara Indonesia yang memiliki konsep sebagai negara Indonesia adalah negara hukum.

Kemudian dalam hal menjamin setiap pemeluk agama untuk beribadah dan menjalankan ajaran agamanya, negara berkewajiban memberikan perlindungan dan jaminan tentang kehalalan produk yang dikonsumsi dan digunakan masyarakat karena produk yang beredar di kalangan masyarakat belum semua terjamin kehalalannya. Kebutuhan konsumen terhadap produk yang beredar di masyarakat, terkadang membutuhkan produk yang mengandung

${ }^{10}$ Musyfikah Ilyas. "Sertifikasi dan Labelisasi Produk Halal Perspektif Maslahat". Jurnal Al-Qadau PERADILAN dan HUKUM KELUARGA ISLAM. Vol. 4 No. 2 Desember 2017 , h. 362 .

${ }^{11} \mathrm{ibid}$. 
unsur tertentu dan terkadang menghindari unsur tertentu pula. Ketidakmampuan konsumen untuk mengevaluasi kehalalan suatu produk, maka diperlukan suatu lembaga yang nantinya berhak untuk mensertifikasi suatu produk. ${ }^{12}$

Negara Indonesia adalah negara hukum, sehingga terdapat jaminan atas hak-hak warganegara yang diatur oleh Undang-Undang Dasar Republik Indonesia Tahun 1945, dalam Pasal 28A yang menyatakan bahwa setiap orang memiliki hak untuk hidup dan bertahan hidup dalam serta Pasal $28 \mathrm{C}$ ayat (1) yang berbunyi bahwa tiap orang memiliki hak untuk melakukan pengembangan diri dengan pemenuhan kebutuhan dasarnya, serta mendapat pendidikan dan memperoleh manfaat dari pengetahuan, teknologi, seni dan budaya guna melakukan peningkatan kualitas hidup dan kesejahteraan umat manusia. ${ }^{13}$

Pangan merupakan kebutuhan utama bagi setiap manusia dalam mempertahankan kehidupannya. Seperti halnya mengkonsumsi pangan sebagai kebutuhan primer setiap manusia. Dalam kemajuan jaman segala bidang termasuk industri pangan dan teknologi yang sangat cepat, adanya dampak perubahan besar dari jaman ke jaman atau dari masyarakat dahulu dengan masyarakat sekarang dalam mengelola maupun mengkonsumsi produk pangan tersebut, sehingga timbulnya banyak isu halal. ${ }^{14}$

Indonesia mulai mengantisipasi perkembangan terkait kehalalan suatu produk dengan UndangUndang No. 33 Tahun 2014 Tentang Jaminan Produk Halal (selanjutnya disebut dengan UU Jaminan Produk Halal). Undang-undang ini dibuat dengan tujuan memberikan kenyamanan, keamanan, keselamatan, dan kepastian ketersediaan produk halal untuk masyarakat dalam mengonsumsi dan menggunakannya guna meningkatkan nilai tambah dan daya saing bagi pelaku usaha dalam berusaha.

Meskipun sudah hampir dua tahun disahkan, namun pelaksanaan UU Jaminan Produk Halal tersebut dirasakan belum banyak mengalami kemajuan. Selain UU Jaminan Produk Halal tersebut, sebenarnya sudah banyak payung hukum pelaksanaan

\footnotetext{
12 ibid.

13 Muhammad Tahir Azhary. (2015). Negara Hukum. Jakarta: Kencana, h. 30.

${ }^{14}$ Abdurrahman Konoras. op.cit., h. 12.
}

pangan halal di Indonesia dibuat sebelumnya yang menyatakan perlunya jaminan halal bagi produk termasuk dalam Pasal 4 huruf (a) Undang-Undang No. 8 Tahun 1999 tentang Perlindungan Konsumen (selanjutnya disebut dengan UU Perlindungan Konsumen) yaitu Hak atas kenyamanan, keamanan, dan keselamatan dalam mengkonsumsi barang dan/ atau jasa. Setiap produk industri pangan haruslah menyediakan aman dan bergizi untuk dikonsumsi oleh masyarakat.Jaminan perlindungan konsumen tersebut merupakan hak warga negara yang tertuang dalam Undang-Undang Dasar 1945. Hal tersebut merupakan suatu perlindungan negara terhadap konsumen terkait dengan produk yang tidak halal.

Pangan menurut Undang-Undang No. 18 Tahun 2012 tentang Pangan yang merupakan pengganti dari Undang-Undang No. 7 Tahun 1996 tentang Pangan (selanjutnya disebut UU Pangan) menyatakan bahwa pangan adalah kebutuhan manusia yang paling utama dan untuk memenuhinya adalah bagian dari hak asasi manusia yang dijamin dalam UUD 1945 yang merupakan bagian dasar untuk mewujudkan sumber daya manusia yang berkualitas. Oleh sebab itu, negara memiliki kewajiban guna perwujudkan tersedianya, terjangkaunya, dan pemenuhan pangan yang cukup, aman, bermutu, dan bergizi seimbang, serta penyediaanya yang tidak bertentangan dengan agama, keyakinan, dan budaya masyarakat yang merupakan tanggung jawab Pemerintah. ${ }^{15}$

Selain itu, dengan tujuan untuk pencegahan pencemaran biologis, kimia, dan benda lain yang mengganggu, merugikan, dan membahayakan kesehatan manusia. Terkait dengan jaminan penyediaan serta keamanan pangan guna kehalalan pangan, yang mana hal tersebut adalah tanggung jawab pemerintah, baik pusat ataupun daerah untuk melakukan pengawasan terhadap pemberlakuan Sistem Jaminan Produk Halal (JPH) yang dipersyaratkan Undang-Undang No. 36 Tahun 2009 tentang Kesehatan (selanjutnya disebut dengan UU Kesehatan).

UU Kesehatan memberikan landasan secara garis besar dalam melakukan produksi dan pengolahan serta pendistribusian makanan dan minuman hasil teknologi rekayasa genetik yang diedarkan agar aman bagi manusia, hewan yang dimakan manusia, dan lingkungan. Makanan dan minuman dini didasarkan

\footnotetext{
${ }^{15}$ May Lim Charity. op.cit., h. 99-108.
} 
pada standar dan/atau persyaratan kesehatan, yang mana hanya dapat diedarkan setelah mendapatkan izin edar sesuai dengan ketentuan peraturan perundangundangan, terutama dalam UU Perlindungan Konsumen, khususnya pada asas manfaat bahwa label halal pada kemasan memiliki manfaat dalam perlindungan konsumen yang mengkonsumsi pangan hasil produk industri. ${ }^{16}$

Asas selanjutnya adalah asas keadilan yang mengupayakan adanya penegakan perlindungan konsumen oleh produsen guna pengamalan nilai keadilan, yang meletakkan secara proposional antara hak dan kewajiban produsen pada konsumen.

Asas Keseimbangan adalah asas selanjutnya dengan makna yang paralel dengan asas keadilan di atas, bahwa konsumen dan produsen sebagai dua pihak yang memiliki kepentingan berbeda, harus sinergis dalam kepentingan mereka untuk mencapai kemaslahatan bersama. Produsen sebagai pihak yang menyajikan produk yang mengandung unsur-unsur yang dapat memberikan kepuasan dan terpenuhi keinginan konsumen terutama dari aspek kehalalannya. ${ }^{17}$

Asas keamanan dan keselamatan yang menyatakan bahwa tanggung jawab social industry atau perusahaan tidak lain adalah memaksimalkan keuntungan perusahaan. Berdasarkan asas tersebut, jelas bahwa bisnis tidak dipandang sebegai sebuah aktifitas dengan tujuan yang tunggal. Konsumen dalam melakukan konsumsi pangan memiliki hak untuk dilindungi yang mana diatur dalam Peraturan Pemerintah No. 28 Tahun 2004 penting dalam pertumbuhan, pemeliharaan, peningkatan kesehatan, dan kecerdasan masyarakat.

Dalam hal ini konsumen secara eksplisit berhak mendapatkan jaminan perlindungan hukum dari adanya undang-undang. Pasal 4 UU Konsumen menetapkan hak-hak konsumen, yaitu: a. hak atas keamanan, kenyamanan serta keselamatan dalam melakukan konsumsi barang dan/atau jasa; b. hak dalam memilih barang dan/atau jasa serta mendapatkan barang dan/jasa dengan nilai tukar dan kondisi serta jaminan yang dijanjikan; c. hak atas

${ }^{16}$ Ali Khomsan. (2004). Pangan dan Gizi untuk Kesehatan. Depok: RajaGrafindo Persada, h. 23.

17 Sofyan Hasan. "Formulasi Hukum dan Pentingnya Jaminan Kepastian Hukum Produk Pangan Halal dalam Hukum Nasional". Jurnal Nurani. Vol. 15 No. 2 Desember 2015, h. 47 74. informasi yang benar, jelas dan jujur dan mengenai kondisi dan jaminan barang dan/atau jasa; d. hak agar pendapatnya atau keluhannya atas barang dan/ atau jasa yang digunakan dapat didengarkan; e. hak guna mendapatkan advokasi, perlindungan serta upaya penyelesaian sengketa perlindungan konsumen secara patut; $f$. hak guna mendapat pembinaan dan pendidikan konsumen; g. hak agar diperlakukan atau dilayani secara benar dan jujur secara tidak diskriminatif; h. hak agar mendapat kompensasi, ganti rugi dan/atau penggantian, apabila barang dan/ atau jasa yang diterima yang tidak sesuai dengan perjanjian atau tidak sebagaimana mestinya; dan i. hak-hak yang diatur dalam perundang-undangan lainnya.

Sedangkan Pasal 55 UU Perlindungan Konsumen diatur mengenai kewajiban konsumen yaitu: a. membaca atau mengikuti petunjuk informasi dan prosedur pemakaian atau pemanfaatan barang dan/ atau jasa, demi keamanan dan keselamatan; b. beritikad baik dalam melakukan transaksi pembelian barang dan/atau jasa; c. membayar sesuai dengan nilai tukar yang disepakati; dan d. mengikuti upaya penyelesaian hukum sengketa perlindungan konsumen secara patut.

Berdasarkan kedua pasal di atas jelas sudah bahwa konsumen berhak mendapatkanInformasi yang benar, jelas, dan jujur tentang kondisi dan jaminan barang dan/atau jasa, dan berkewajiban membaca dan ikut petunjuk dalam informasi, prosedur pemakaian atau pemanfaatan barang dan/ atau jasa, untuk keamanan dan keselamatan. Dalam hal ini, kewajiban pengusaha sebagai produsen yaitu untuk menyediakan dan memberikan informasi yang benar, jelas, dan jujur mengenai kondisi barang atau jasa, serta memberi penjelasan penggunaan, perbaikan, dan pemeliharaan atas produk yang dihasilkan.

Berdasarkan hak-hak konsumen tersebut, maka penyampaian informasi mengenai produk harus dapat memberikan kepastian kepada konsumen. Hal tersebut dilakukan untuk melindungi hakhak konsumen. Maka perlu ditekankan bahwa penyampaian informasi mengenai produk makanan harus memberikan jaminan bahwa produk makanan tersebut adalah halal.

Peraturan-peraturan di atas sangatlah mendukung kebenaran halal, bahwa setiap produsen yang 
melakukan produksi maupun sebagai konsumen pangan di dalam wilayah Indonesia wajib memeriksa dulu pangan pada lembaga penguji dan penelitian yang telah diakreditasi sesuai dengan ketentuan peraturan perundang-undangan.

\section{Sertifikat Halal Menjamin Keamanan Produk Bagi Konsumen}

Sertifikasi halal atau halal certification adalah jaminan keamanan bagi umat muslim untuk dapat mengkonsumsi suatu produk makanan sesuai ajaran agama Islam. Sertifikasi halal juga menandakan kualitas, kebersihan, dan higienis suatu produk. Produk yang bersertifikat halal dapat dibuktikan dengan logo halal pada kemasan produk. Produk ini terbukti lolos uji halal oleh MUI. Produk yang terbukti Halal telah melalui seragkaian proses dan pengujian yang terbukti tidak mengandung najis dan diperbolehkan untuk dikonsumsi. Kesadaran halal atau halal awareness merupakan tingkat pemahaman umat muslim dalam mengetahui isu-isu terkait konsep halal. Pengetahuan tersebut termasuk didalamnya memahami apa itu halal dan bagaimana proses produksi suatu produk sesuai standar halal dalam Islam. ${ }^{18}$

Sertifikasi halal merupakan jaminan keamanan bagi seorang konsumen muslim untuk dapat memilih makanan yang baik baginya dan sesuai dengan aturan agama. Produk makanan yang memiliki sertifikat halal adalah produk yang di dalam proses pengolahannya memenuhi standar dalam keamanan dan kebersihannya. Sertifikasi bermakna adanya jaminan tertulis berupa sertifikat dari pihak ketiga yang independen, seperti dari SUCOFINDO. Sertifikat ini menjelaskan bahwa suatu produk beserta proses produksinya telah memenuhi persyaratan standar tertentu. ${ }^{19}$

Sertifikat Halal menjamin keamanan produk bagi konsumen Sertifikasi halal atau halal certification adalah jaminan keamanan bagi umat muslim untuk dapat mengkonsumsi suatu produk makanan sesuai ajaran agama Islam. Sertifikasi halal juga menandakan kualitas, kebersihan, dan higienis

\footnotetext{
18 Hasyan Sofyan. "Kepastian Hukum Sertifikasi dan Labelisasi Halal Produk Ringan”. Jurnal Dinamika Hukum. Vol. 14 No. 2 Mei 2014.

19 SUCOFINDO, "Ini bedanya sertifikasi dan pengujian yang wajib anda ketahui", https://www.SUCOFINDO.co.id. Diakses tanggal 7 Mei 2019.
}

suatu produk. Produk yang bersertifikat halal dapat dibuktikan dengan logo halal pada kemasan produk. Produk ini terbukti lolos uji halal oleh MUI.

Pembuktian produk halal dilakukan melalui proses dan pengujian tidak mengandung najis dan boleh dikonsumsi. Kesadaran halal atau halal awareness merupakan tingkat pemahaman umat muslim untuk mengetahui isu-isu terkait konsep halal. Pengetahuan tersebut termasuk didalamnya memahami apa itu halal dan bagaimana proses produksi suatu produk sesuai standar halal dalam Islam.

Sertifikasi halal menjamin keamanan bagi konsumen muslim untuk memilih makanan yang baik dan sesuai dengan aturan makanan. Produk tersebut merupakan produk yang didalam proses pengolahannya telah memenuhi standar dalam keamanan dan kebersihannya. Sertifikasi bermakna adanya jaminan tertulis berupa sertifikat dari pihak ketiga yang independen, seperti dari SUCOFINDO.

Sertifikat tersebut memiliki penjelasan bahwa produk dan proses produksi telah sesuai dengan standar tertentu. Kehadiran ini jelas diperlukan, sebagai negara yang mayoritas beragama Islam, apalagi dengan perkembangan teknologi dalam pembuatan makanan yang semakin beragam.

Jumlah populasi penduduk Indonesia menurut data sensus tahun 2010 adalah 237,64 juta jiwa, dengan 207,18 juta $(87,18 \%)$ adalah pemeluk agama Islam. Fakta ini menempatkan Indonesia sebagai pasar potensial dan juga produsen produkproduk halal terpenting di dunia. Sebenarnya potensi konsumen tidak hanya pada muslim saja, namun juga pada agama lain yang memiliki nilai-nilai kepercayaan yang sama.

Label halal memberikan kemudahan bagi konsumen dalam melakukan identifikasi pada produk. Perihal tersebut terdapat pada bermacammacam produk yang mana dalam penempelannya harus mendapatkan uji kehalalan dari MUI terlebih dahulu. $^{20}$

\footnotetext{
${ }^{20}$ Shilachul Alfinul Alim, M Kholid Mawardi, dan Aniesa Samira Bafadhal. "Pengaruh Persepsi Label Halal dan Kualitas Produk Terhadap Keputusan Pembelian Produk Fesyen Muslim (Survei pada Pelanggan Produk Zoya Muslim di Kota Malang)". Jurnal Administrasi Bisnis (JAB). Vol. 62 No. 1 September 2018, h. 132 .
} 
Sebelum mendapatkan sertifikat halal, seorang produsen/perusahaan harus melakukan pendaftaran sertifikasi halal dan memenuhi persyaratan sertifikasi halal. Saat ini sedang diupayakan untuk mewajibkan pada semua produk makanan dan minuman dan nantinya akan dituangkan dalam Rancangan Peraturan Pemerintah tentang Jaminan Produk Halal pada tanggal 17 Oktober 2019.

Dimana rancangan tersebut telah disepakati oleh tujuh kementerian, yaitu Kementerian Agama, Kementerian Koordinator Bidang Perekonomian, Kementerian Perindustrian, Kementerian Pertanian, Kementerian Perdagangan, Kementerian Kesehatan, dan Kementerian Koordinator Bidang Pembangunan Manusia dan Kebudayaan (PMK) untuk selanjutnya akan dibahas bersama kementerian Sekretariat Negara sebelum disahkan oleh Pemerintah.

Rancangan Peraturan Pemerintah ini telah mendapatkan persepsi yang sama termasuk juga stakeholder dalam dan luar negeri. Hal tersebut diakibatkan karena sertifikasi tersebut untuk produk dalam negeri maupun impor dan dikeluarkan oleh Badan Pengelola Jaminan Produk Halal, selanjutnya disebut dengan BPJH melalui sinergi dengan lembaga lainnya seperti Badan Pengawas Obat dan Makanan, atau BPOM.

Kewenangan Majelis Ulama Indonesia, atau MUI adalah memberikan fatwa kehalalan, mengesahkan auditor, serta memberikan kewenangan kepada lembaga pemeriksa halal, sebagai acuan untuk mendapatkan sertifikat pada BPJPH. Diharapkan pada RPP ini dilakukan regulasi teknis, termasuk PMA, yang mana untuk melakukan adaptasi dan sosialisasi sertifikat halal akan berjalan sekitar tiga sampai lima tahun. Dalam pembahasan awal, Kementerian Agama sempat menekankan dua pasal dalam RPP yang dianggap membutuhkan pendalaman lebih matang.

Pertama, Pasal 2 yang menyatakan agar setiap produk wajib bersertifikat halal. Pertimbangannya, apakah aturan ini bisa dilakukan secara bertahap atau tidak.Hal tersebut menyebabkan meningkatnya kebutuhan untuk auditor halal. Sedangkan tahapan yang dilakukan adalah mengikuti pelatihan $\mathrm{SJH}$ (Sistem Jaminan Halal); Menerapkan Sistem Jaminan Halal (SJH); Menyiapkan dokumen sertifikasi halal; Melakukan pendaftaran sertifikasi halal Melakukan monitoring preaudit dan pembayaran akad sertifikasi;
Pelaksanaan audit; Melakukan monitoring pasca audit; Memperoleh Sertifikat halal. Fatwa MUI No. 01 Tahun 2011 mengenai "Penetapan Produk Halal", bahwa makanan, minuman, obat-obatan, kosmetik, dan lain-lain yang akan dikonsumsi atau dipergunakan umat yang beragama Islam harus diperhatikan dan diyakini kehalalannya dan kesuciannya. Salah satu hak konsumen untuk menggunakan produk yang akan dibeli adalah adanya informasi dalam produk tersebut, baik secara langsung maupun tidak langsung.

Informasi secara langsung terdapat pada kemasan produk yang dibeli, mulai dari keterangan produk, komposisi, cara pakai, label halal, tempat produksi. Fungsi utama label halal adalah membantu konsumen memilih produk tanpa keraguan. Umumnya, setiap muslim akan melihat produk dengan label halal adalah jaminan aman untuk di konsumsi.

Dengan jaminan ini, maka pasar tidak hanya terbatas di dalam negeri, namun pangsa pasar muslim di luar negeri yang sangat luas menjadi terbuka lebar. Peran SUCOFINDO dalam Sertifikasi Halal Perusahaan BUMN, SUCOFINDO telah menandatangani nota kesepahaman (MoU), sertifikasi halal bersama Nahdatul Ulama sebagai model perseroan dalam mengarungi persaingan bisnis inspeksi. Selain itu, SUCOFINDO telah mendapat pengakuan dari berbagai lembaga internasional, seperti International Electrotechnical Commision (IEC) dan FOSFA.

\section{Eksistensi SUCOFINDO dalam Menjamin Kehalalan Suatu Produk Melalui Sertifikasi Halal}

BPJPH dan SUCOFINDO sebagai lembaga yang mendukung proses pengujian dan sertifikasi. Pilot project tersebut dimaksudkan sebagai sarana latihan bagi BPJPH dan SUCOFINDO untuk menyiapkan kapasitas auditor dan laboratorium agar dapat memfasilitasi kepentingan usaha, terutama UMKM.

Hal ini disebabkan adanya keterbatasan dari UMKM untuk melakukan akses dana, fasilitas, informasi, teknologi, dan tata laksana, maka dilakukan untuk memberikan fasilitas 9 UMKM di kantin SUCOFINDO, Kemenko PMK dan Kementerian Agama. Untuk itu, SUCOFINDO menyiapkan laboratorium untuk mendukung sertifikasi halal. Keberadaan laboratorium ini tentu 
memudahkan kerja Majelis Ulama Indonesia (MUI) sebagai otoritas yang mengeluarkan fatwa halal. ${ }^{21}$

Perseroan dapat memberikan nilai tambah bagi pengguna jasa pengujian dan sertifikasi berupa kemudahan dalam transaksi internasional. jadi, industri elektronik Indonesia tidak perlu melakukan pengujian produk di negara tujuan ekspor, manakala dinyatakan lulus uji standar oleh SUCOFINDO.

Terkait dengan jasa pemastian dalam pemenuhan standar SNI, SUCOFINDO yag diakreditasi oleh Komite Akreditasi Nasional ini dapat melayani sertifikasi untuk 140 jenis produk industri. Saat ini tercatat sejumlah perusahaan raksasa di Indonesia mempercayakan urusan pengoperasian laboratorium, pengujian, kalibrasi dan lain-lain, antara lain seperti PT Freeport Indonesia, PT Berau Coal Tbk, PT Bukit Asam Tbk, Pertamina EP, BP Tangguh, dan lainnya.

BPJPH adalah badan pemerintah yang memeliki kewenangan untuk sertifikasi produk halal di Indonesia, sedangkan sertifikat halal MUI adalah fatwa tertulis MUI yang memberikan pernyataan tentang kehalalan suatu produk sesuai dengan syariat Islam. Sertifikat ini adalah syarat untuk pencantuman label halal pada kemasan produk.

Mengenai eksistensi SUCOFINDO dalam penyelenggaraan dan wewenang konsumen serta produsen dalam mengelola usaha yang halal untuk memenuhi sertifikasi halal untuk negara Indonesia sehingga layak guna pakai dan atau layak fungsi untuk masyarakat, antara lain: 1. Melakukan penetapan norma, standar, prosedur dan kriteria JPH; 2. Melakukan penerbitkan dan mencabut sertifikat halal dan label halal pada suatu produk; 3. Melakukan registrasi, sertifikat halal pada produk luar negeri; 4. Melakukan sosialisasi, edukasi, dan publikasi produk halal. SUCOFINDO selama ini telah menyediakan jasa pengujian untuk produk seperti makanan, minuman, kosmetik dan sebagainya. SUCOFINDO memiliki laboratorium yang memiliki peralatan dengan teknologi terkini untuk mendukung proses uji halal, diantaranya PCR (Polumerase Chain Reaction) yang dapat mendeteksi DNA Babi dan

${ }^{21}$ Akim, Neneng Konety, Chandra Purnama, Monita Hizma Adilla, "Pemahaman Usaha Mikro, Kecil dan Menengah (UMKM) di Jatinangor terhadap Kewajiban Sertifikasi Halal Pada Produk Makanan”. Kumawula. Vol. 1 No. 1 April 2018, h. 31 . peralatan Chromatography (GC dan HPLC) untuk mendeteksi zat alcohol atau ethanol. ${ }^{22}$

\section{PENUTUP \\ Kesimpulan}

Pangan merupakan kebutuhan utama bagi setiap manusia dalam mempertahankan kehidupannya. Sedangkan masyarakat di Indonesia sebagian besar adalah beragama Islam, sehingga perlu kiranya pemerintah membuat kebijakan mengenai sertifikasi halal. Indonesia mulai mengantisipasi perkembangan terkait kehalalan suatu produk dengan UndangUndang No. 33 Tahun 2014 tentang Jaminan Produk Halal, selanjutnya disebut dengan UU Jaminan Produk Halal, dengan tujuan memberikan kenyamanan, keamanan, keselamatan, dan kepastian ketersediaan produk halal untuk masyarakat dalam mengonsumsi dan menggunakannya guna meningkatkan nilai tambah dan daya saing bagi pelaku usaha dalam berusaha. Selain itu pada Pasal 4 huruf (a) UndangUndang No. 8 Tahun 1999 tentang Perlindungan Konsumen, yaitu Hak atas kenyamanan, keamanan, dan keselamatan dalam mengkonsumsi barang dan/ atau jasa. Setiap produk industri pangan haruslah menyediakan aman dan bergizi untuk dikonsumsi oleh masyarakat. Selanjutnya Undang-Undang No. 18 Tahun 2012 tentang Pangan yang merupakan pengganti dari Undang-Undang No. 7 Tahun 1996 tentang Pangan, selanjutnya disebut UU Pangan, menyatakan bahwa pangan adalah kebutuhan manusia yang paling utama dan untuk memenuhinya adalah bagian dari hak asasi manusia yang dijamin dalam UUD 1945 yang merupakan bagian dasar untuk mewujudkan sumber daya manusia yang berkualitas. Dan terakhir adalah Undang-Undang No. 36 Tahun 2009 tentang Kesehatan, yang mewajibkan adanya izin edar sesuai aturan yang berlaku bagi makanan dan minuman hasil teknologi rekayasa genetik.

\section{Rekomendasi}

Pemerintah harus lebih jeli dalam pengawasan untuk menjamin kehalalan setiap produk. Sebagai upaya mengurangi banyaknya isu-isu dari pihak yang kurang bertanggung jawab terhadap produknya.

${ }^{22}$ Dwi Murdaningsih. (2017). Jaminan Produk Halal Makin Jadi Perhatian. https://www.republika.co.id/berita/dunia-Islam/ Islam-nusantara/17/03/14/omskvz368-jaminan-produk-halalmakin-jadi-perhatian, diunduh pada tanggal 23 September 2019. 
Pemerintah juga harus lebih tegas dalam memberikan Jaminan Produk Halal (JPH) dalam memberikan kewenangan kepada lembaga penelitian dan pengujian kehalalan yang sudah terakreditasi untuk memberikan lablelisasi halalnya.

\section{DAFTAR PUSTAKA}

\section{Peraturan Perundang-Undangan}

Undang-Undang Dasar 1945.

Undang-Undang Nomor 18 Tahun 2012 tentang Pangan.

Undang-Undang Nomor 8 Tahun 1999 tentang Perlindungan Konsumen.

Undang-Undang Nomr 36 Tahun 2009 tentang Kesehatan.

Undang-Undang Nomor 33 Tahun 2014 tentang Jaminan Produk Halal.

\section{Buku:}

Abdurrahman Konoras. (2007). Jaminan Produk Halal di Indonesia, Perspektif Hukum Perlindungan Konsumen. Jakarta: Rajawali Press.

Ali Khomsan. (2004). Pangan dan Gizi untuk Kesehatan. Depok: RajaGrafindo Persada.

Muhammad Tahir Azhary. (2015). Negara Hukum. Jakarta: Kencana.

R. Hendra Halwani. (2003). Ekonomi Internasional dan Globalisasi Ekonomi. Jakarta: Ghalia Indonesia.

\section{Jurnal:}

Akim, Neneng Konety, Chandra Purnama, Monita Hizma Adilla, "Pemahaman Usaha Mikro, Kecil dan Menengah (UMKM) di Jatinangor terhadap Kewajiban Sertifikasi Halal Pada Produk Makanan”. Kumawula. Vol. 1 No. 1 April 2018, h. 31 .

Hasyan Sofyan. "Kepastian Hukum Sertifikasi dan Labelisasi Halal Produk Ringan”. Jurnal Dinamika Hukum. Vol. 14 No. 2 Mei 2014.
May Lim Charity. "Jaminan Produk Halal di Indonesia”. Jurnal Legislasi Indonesia. Vol. 14 No. 01 Maret 2017, h. 99-108.

Musyfikah Ilyas. "Sertifikasi dan Labelisasi Produk Halal Perspektif Maslahat". Jurnal Al-Qadau PERADILAN dan HUKUM KELUARGA ISLAM. Vol. 4 No. 2 Desember 2017, h. 362.

Shilachul Alfinul Alim, M Kholid Mawardi, dan Aniesa Samira Bafadhal. "Pengaruh Persepsi Label Halal dan Kualitas Produk Terhadap Keputusan Pembelian Produk Fesyen Muslim (Survei pada Pelanggan Produk Zoya Muslim di Kota Malang)". Jurnal Administrasi Bisnis (JAB). Vol. 62 No. 1 September 2018, h. 132.

Sofyan Hasan. "Formulasi Hukum dan Pentingnya Jaminan Kepastian Hukum Produk Pangan Halal dalam Hukum Nasional”. Jurnal Nurani. Vol. 15 No. 2 Desember 2015, h. 47-74.

Syafrida. "Sertifikat Halal Pada Produk Makanan dan Minuman Memberi Perlindungan dan Kepastian Hukum Hak-Hak Konsumen Muslim”. Jurnal Adil. Vol. 7 No. 2 Desember 2016, h. 161.

\section{Website:}

Dwi Murdaningsih. (2017). "Jaminan Produk Halal Makin Jadi Perhatian". https://www. republika.co.id/berita/dunia-Islam/Islamnusantara/17/03/14/omskvz368-jaminanproduk-halal-makin-jadi-perhatian, diunduh pada tanggal 23 September 2019.

SUCOFINDO, "Ini bedanya sertifikasi dan pengujian yang wajib anda ketahui", https:// www.SUCOFINDO.co.id. Diakses tanggal 7 Mei 2019.

SUCOFINDO. "sejarah singkat SUCOFINDO", https://www.SUCOFINDO.co.id/id/sejarahsingkat-SUCOFINDO\#. Diakses tanggal 7 Mei 2019.

SUCOFINDO. https://www.SUCOFINDO.co.id/. Diakses pada tanggal 30 Oktober 2019. 